\title{
THE DEVELOPMENT OF CAPACITY BUILDING TO IMPROVE THE QUALITY OF HUMAN RESOURCES AMONG SMALL AND MEDIUM ENTERPRISES
}

\author{
Dheasy Amboningtyas, Yulianeu \\ Faculty of Economics, Universitas Pandanaran Semarang \\ E-mail: dheasey@unpand.ac.id
}

\begin{abstract}
Small and medium enterprises (SME) are those of business groups which are believed to survive even when economic crisis occurs. The increasing number of those business groups allows more job opportunities for people, and thus it could impact positively towards the decreasing number of unemployments. Unfortunately, the level of managerial skills and ability among SME are relatively low due to a number of SME entrepreneurs who still hold Bachelor degrees. In addition, the fact indicates that the quality of SME resources is low, especially in the fields of management, organization, mastery of technology and marketing. The low educational level among small and medium entrepreneurs was apparently not supported by capacity building through training, education, and programmed comparative studies. On the other hand, human resources (HR) also plays an important role in gaining success, because sophisticated and complete facilities cannot guarantee the success of an organization if they are not supported by quality of human resources who will use the facility. This study aims at examining strategies that can be used by SME as an effort to improve HR capacity using purposive sampling method; and then the data is analyzed using multi-linear regression. The result shows that capacity development which is proxied through education, skills and ability variables partially or simultaneously have positive and significant effects on HR development.
\end{abstract}

Keywords: capacity building, small and medium enterprises (SME), quality of human resources

\section{INTRODUCTION}

Small and medium enterprises (SME) are those of business groups which are believed to survive even when economic crisis occurs. The increasing number of those business groups allows more job opportunities for people, and thus it could impact positively towards the decreasing number of unemployments. In the current era of advanced information and technologies, challenges and competitiveness seem unavoidable; hence it requires professionalism in all aspects of economy. In addition, this advanced period also causes a new phenomenon which has never existed in the previous era. As the consequence, economic players are expected to always innovate in order to be able to compete with other economic players. As one of 
economic players, small and medium enterprises (SME) are expected to have better quality in terms of product, services, costs, or human resources.

Even though the number of SMEs has increased, it does not correlate positively with the educational background of the staff which is relatively low. There are still few of them who hold bachelor degree. As the result, the quality of the human resources is reasonably low. Some of them are still lack of competence in managing, organizing, marketing, and operating technologies. The worse is, there is still no effort from the SME actors to conduct capacity building such as in the form of training, learning, or doing comparative study. Generally, they run their businesses merely based on their experiences. Capacity building is, unfortunately, still beyond their priority.

Jan (2010) revealed that the common challenges encountered by the SME in Indonesia include the low quality of human resources, minimum funding, limited access to funding, and how to manage the funding. It is strengthened by Dharma (2010) who argued that among those challenges faced by the SME are marketing the products, low technologies, low financial management, the quality of human resources, and funding.

One of the SME expected to be able to challenge the global competition is the one located in Kec. Tugu, that is by improving their performance through capacity building. Capacity building, in general, is a process or activity to improve the ability of a person, groups, organizations, or a system in order to achieve an expected outcome or better performance (Brwon et al., 2001).

From the previous discussion, the researchers then create two research questions, namely "is capacity building becoming one of the essential elements in empowering human resources at SME in Kec. Tugu? And what are the strategies applied by the SMEs in Kec. Tugu to upgrade their human resources through capacity building?"

The limitation of the study is on the financial portfolio at SME in Kec. Tugu, Semarang. The purposes of the study are (1) To know whether capacity development becoming one of essential elements in empowering the human resources at SME in Kec. Tugu; (2) To know strategies applied by the SME in Kec. Tugu to develop their human resources through capacity building.

\section{LITERATURE REVIEW}

In the Indonesian economic system, small and medium enterprises (SME) are considered as business groups which are big in numbers and could survive even when economic crisis occurs. As stated in Law No. 20, 2008 concerning Micro, Small and Medium Enterprises (SME), there are some criteria used to describe the definitions and the criteria of Micro, Small and Medium Enterprises as in Table 1. The Criteria of SME, as stated in Law No. 20, 2008 concerning Micro, Small and Medium Enterprises (SME), the criteria of SME can be classified based on the number of assets and turnover owned by a business. 
The Development of Capacity Building to Improve The Quality $\mid 77$ of Human Resources Among Small and Medium Enterprises

Table 1. SME Criteria

\begin{tabular}{lll}
\hline Business & Criteria & \\
\hline \multirow{3}{*}{ Micro } & Assets & Turnover \\
\cline { 2 - 3 } Small & Max $50 \mathrm{mil}$ & Max $300 \mathrm{mil}$ \\
Medium & $>50-500 \mathrm{mil}$ & $>300 \mathrm{mil}-2,5 \mathrm{bil}$ \\
Source: Ministry & $>500$ mil $-10 \mathrm{bil}$ & $>2,5-5 \mathrm{bil}$ \\
\hline
\end{tabular}

Human resources (HR) are human potentials which are considered as non-material/ nonfinancial assets. They function as a driving force for organizations to keep their existence. Furthermore, human resources play important roles in organization, not only because they are needed but also because they have intellectual competence. The quality of human resources is mostly related with qualifications, competences, and skills.

Matutina (2001) stated that human resources (employees) refer to: (1) their knowledge in science and technology gained from learning process and experiences; (2) their skills in manipulating/ working on an object physically; (3) their abilities or attitudes in performing their duties in entrepreneurships.

Slightly similar, Ardiana et al (2010) used the following indicators to develop the quality of human resources, including (1) knowledge, which refers to the knowledge of business management, the knowledge of products and services, and the knowledge of customers, promotion, and marketing; (2) skill, which covers production skill, communication skill, team-working in organization, supervision, finance, administration, and accounting; (3) ability, which refers to the ability to manage the business, to make decisions, to act as a leader, to control the business, and to make innovation relating to current situation in the business.

Additionally, Ruhana (2012) argued that a number of efforts can be done to improve the quality of the human resources, such as (1) formal education, which aims at equipping learners with basic knowledge, theory, and logical thinking; general knowledge, analytical skills, and the development of character and personality; (2) work training, which is addressed to develop professional competence and to prioritize practical ecperiences over theoretical framework; (3) internship, with target to improve both technical knowledge and working skill by observing other experienced employees, then imitating the way the experienced work, before finally they could do the job independently and proficiently, so that they could find more practical and efficient ways in doing their jobs.

In his work entitled the human glossary, William R. Tracey (in Haryanto, 2014) stated human resources as people who staff and operate an organization. They also function as connector between the organization and other stakeholders relating to various issues such as compensation, recruitment, work management, and training in order to running effectively. The function of human resources is managed 
systematically by using standard and established procedure run by trained and dedicated staffs under human resources management.

Furthermore, human resources undoubtedly play central roles in any organizations which are formed based on various visions for humans' inetersts, thus they are managed and controlled by human beings. Grindle (1997) stated the definitions of human resources capacity as "initiatives to develop human resource generally seek the capacity of individuals to carry out their profesional and technical responsibilities".

It is strengthened by Milen (2006) who defined capacity as the ability of individuals, organizations or systems to run their functions effectively, efficiently, and continuously. While Morgan (as cited in Milen, 2006) described capacity as ability, skills, understanding, attitudes, values, relationships, behavior, motivation, resources, and conditions which allow individuals, organizations, networkings/ sectors, and broader systems so that they can carry out their functions well to achieve the expected development goals that have been set.

The idea is relevant with the concept of capacity development as stated by Grindle (1997) saying that capacity development is "ability to perform appropriate task effectively, efficiently and sustainable." In addition, Grindle (1997) even mentioned that capacity development refers to "improvement in the ability of public sector organizations."

Capacity building can be described as a process experienced by individuals, groups and organizations to improve their competence in carying out their functions/ roles and achieve the desired results (Morgan as cited in Harris, 2005). From the definition, at least there are two important points: 1) capacity building mostly about development process and internal growth, and 2) capacity building process should focus on result oriented.

From the previous discussion, it can be concluded that capacity building is a process which is believed to develop the competence of individuals, organizations or systems to achieve the desired goals. It is in accordance with Eichler (2002) who claimed that capacity building is a process to develop individuals, groups, organizations, communities and socities to achieve the set goals.

While according to Morrison (2001), capacity building is a series of strategies designed to increase efficiency, effectiveness, and responsiveness of performance. Further, Morrison indicated that capacity building is a learning process, starting from the flow of the needs to experience something, reducing ignorance and uncertainty in life, and then developing the abilities needed to adapt with new changes.

Referring to the previous definitions given by the experts, we may conclude that the goals of capacity building can be divided into two, namely general purpose which focuses on the sustainability of a system, and specific purpose which focuses on generating better performance. Those purposes can be 
The Development of Capacity Building to Improve the Quality | 79 of Human Resources Among Small and Medium Enterprises

observed through the following aspects: (1) Time efficiency and resources to achieve the expected outcomes; (2) Effectiveness in form of appropriateness of the business to carry out the desired results; (3) Responsiveness in how to synchronize both needs and abilities in accordance with that purposes. (4) Learning process which is indicated by the performance of individuals, groups, organizations and systems.

According to Gandara (2008), capacity building is characterized by the following indicators: (a) is an ongoing process; (b) is an internal process; (c) is built based on the available resources; (d) having its own intrinsic values; (e) dealing with changes; (f) using integrated and holistic approaches.

From those indicators, capacity building can be seen as an ongoing process which is not merely based on result orientation; however it is an ongoing learning process to be able to survive against environmental changes that occur from time to time.

Capacity building is not a process starting from zero or nothing, yet it starts from maximizing the available resources to be processed to develop the quality of the individuals, groups, organizations and systems in order to be able to survive against environmental changes that occur continuously. Capacity building is not merely addressed to gain quality development on one certain component of a system, it is also addressed to all components, not partial but holistic, since capacity building is a multi-dimensional and dynamic which is characterized by the existence of multi-activities and learning characteristics for all components in a system that lead to the contribution towards the realization of collective performance.

\section{METHOD}

This study used subjective data, which is data in the form of opinions, attitudes, experiences or characteristics of a person or group of people who become the subject of the study. In this matter, the current study used respondents' responses towards a number of questions given during interview, both oral and written responses.

In addition, the writer used primary data which is collected through distributed questionnaires which contains a number of statements relating to variable data to be analyzed.

The current study used Micro, Small and Medium Enterprises (SME) in Kec. Tugu as the population; while the sample of the population is taken using purposive sampling method which is chosen based on certain criteria (Sugiyone, 2015). The reason of using this method is due to the limited number of the managers who can be respondents. The writer could not predict the number of returned responses from the contacted samples, thus purposive sampling is used to all populations of 214 SME. The returned responses then become the primary data to be processed.

To collect the data, the writer used questionnaires. The questionnaires contain a number of statements or questions asking whether capacity development is one of important elements in developing human resources and to know what 
strategies used by the SME to improve the capacity of their human resources. The responses then scored using Likert scale.

Thinking framework is a conceptual model on how to relate theory with various factors that have been identified. It is an understanding that underlies other understandings, and becomes the foundation for every thought or process from the whole study that will be carried out (Sugiyono, 2015).

Based on the analysis on the theoretical basis in order to see capacity building as a strategy in improving the quality of human resources in the SME located in Kec. Tugu, so the framework of this study as seen on Figure 1:

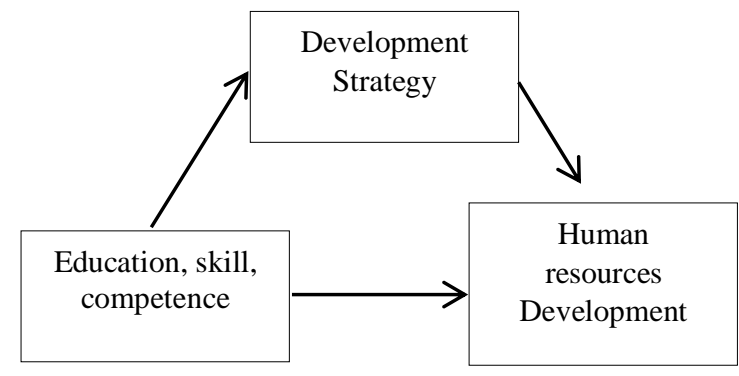

Figure 1. Model of SME Development Strategy

The data is collected through guided interview. The questionnaire was used as guidance so that the interview could be more structured and standardized. Additionally, the interview was applied as a complement to obtain data that cannot be collected through a questionnaire. Interview also functions to cross-check the collected data.

Before carrying out the feasibility test, first the data is tested its reliability, validity and classic assumptions to see whether the data is feasible to use. Reliability Test is used to see whether the instrument is reliable enough to be used as a tool to collect data (Arikunto, 2013). A reliable instrument is an instrument which produces the same data even though it has been used several times to measure the same object.

Test Validity is used to indicate the level or validity of an instrument
(Arikunto, 2013); while Classical Assumption Test is used to know or to test the feasibility of the regression model used in the current study. Another goal of the test is to ensure that the regression model used has data that has normal distribution, is free from autocorrelation, multicollinearity, and heteroscedasticity. Based on the reliability, validity and classical assumption tests, the result shows that the data in this study have passed the test and are feasible to use onto the next analysis stage.

Regression is a kind of statistical method which can be used to see whether there is a relationship (causal or cause and effect relationship) or not and displayed in the form of a systematic model or equation. $\mathrm{T}$ test is used to test the variables which influence the independent variable towards the dependent variable individually. F 
test is used to test the effect of independent variables altogether towards the dependent variables. $\mathrm{R}^{2}$ analysis ( $\mathrm{R}$ Square) or determination coefficience is basically used to measure how far the ability of the model in explaining the variation of dependent variables.

\section{RESULTS AND DISCUSSION}

The results of linear regression are as follows: (a) Constants $(\alpha)=$ 1.682, meaning that if education, skills, and abilities are equal to 0 or omitted, then HR development will increase by 1.682 percent. (b) The value of $\mathrm{b} 1=0.614$, indicating that the education variable has a positive influence on improving HR development.

If there is a one percent increase on the education variable, then HR development will increase by 61.4 percent assuming that the skill and ability variables are constant. (c) The value of b2= 0.082 , implying that the skill variable has a positive influence on improving HR development. If there is a 1 percent increase in the skill variable, HR development will increase by 8.2 percent assuming that education and ability variables are constant. (d) $\mathrm{B} 3=0.170$ which means that the ability variable has a positive influence on improving HR development. If there is a 1 percent increase in the ability variable, then HR development will increase by 17 percent assuming that education variables and skills are constant. Then the regression equation can be written as follows:

$$
\begin{gathered}
\mathrm{Y}=1.682+0.614 \mathrm{X} 1+0.082 \mathrm{X} 2+ \\
0.170 \mathrm{X} 3+\mathrm{e}
\end{gathered}
$$

Based on the results of the regression analysis, then: (a) The education variable has a value of $t_{\text {count }}$ of 11.396 with a significance level of 0.000 ; because the value of $t_{\text {count }}$ is 11.396> $t_{\text {table }} 1.65251$ and significance value (Sig.) is 0.000 $<0.05$ and positive, it can be concluded that education (X1) partially influences HR development.

Education is one of important factors in improving the quality of human resources. Education provides the basis of general knowledge, analytical skills and can shape the character and personality of HR, therefore the better the level of their education. The HR is expected to find better ways which are more practical and efficient in carrying out their work so that it can improve the performance of SME. (b) The skill variable has a value of $t_{\text {count }}$ of 1.568 with a significance level of 0.018 , because the value of $t_{\text {count }}$ is $1.568>$ $t_{\text {table }} 1.65251$ and the significance value (Sig.) is $0.018<0.05$ and it is positive, it can be concluded that skill (X2) partially affects HR development. The skill itself is divided into 2, namely hardskill and soft skill.

The need for professional human resources who have strong skills is highly proposed and it has even become the demands in the work. Specifically in the current work world which is much influenced by the changes in markets, economics and technology. HR who has strong intelligence and skills will be able to provide excellent performance. c) The ability variable has a $t_{\text {count }}$ of 2.976 with a significance level of 0.003 , because the value of $t_{\text {count }}$ is $2.976>t_{\text {table }}$ 
1.65251 and the significance value (Sig.) is $0.003<0.05$ and positive, it can be concluded that ability (X3) partially influences HR development.

Ability is a competence to carry out something that is realized through actions to improve work productivity. Therefore, it can be said that the ability possessed by HR will enable the completion of each work effectively and efficiently without any difficulties and it may result in a good performance. From the test, it results $\mathrm{F}_{\text {count }} 197.388>$ $F_{\text {table }}(2.70)$ with a significance of 0.000 smaller than 0.05 , so it can be concluded that education, skills, and abilities altogether have significant effects on HR development. The results of the analysis of the determination coefficient in multiple linear regression with the value of $\mathrm{R}$ (Adjusted R Square) 0.754, which means the influence of the variables of education, skills, and abilities on employee performance variable is $75.4 \%$, while the rest is influenced by other factors.

\section{REFERENCES}

Ardiana I, Brahmayanti I, Subaedi. 2010. Kompetensi SDM UKM dan Pengaruhnya Terhadap Kinerja UKM di Surabaya. Jurnal Manajemen dan Kewirausahaan.12 (1).

Brown, Lisanne, Anne LaFond, and Kate Macintyre. 2001. Measuring Capacity Building, Carolina.

Dharma S. 2010. Manajemen Kinerja. Yogyakarta (ID): Pustaka Pelajar.

Gandara Rida. 2008. Capacity Building Dosen Pada Jurusan

\section{CONCLUSION}

From the results of the study, it can be concluded that capacity development which is proxied through education, skills and ability variables partially or simultaneously have positive and significant effects on HR development. HR is an important capital, not only as an organization resource that is needed and employed, but HR also functions as motor in an organization (SME) to keep the existence of the organization. Thus, it can be said that developing human resources by improving the quality of education, skills and abilities can make SMEs stronger and able to compete in both local and global business world.

Lastly, capacity building requires quality resources, which can be obtained through coaching, training and guidance programs. Each SME certainly has its own needs and uniqueness, so that capacity building programs should be tailored to the needs and conditions of each SME.

di Perguruan Tinggi Badan

Hukum Miliki Negara. Jurnal Fakultas Ilmu Pendidikan UPI. Bandung.

Grindle, M.S., 1997. Getting Good Government: Capacity

Building in The Public Sector Of Developing Countries. Boston, MA. Harvard Institute for International Development.

Haryanto, 2014. Pengembangan Kapasitas Kelembagaan (Institutional Capacity Development) (Teori dan Aplikasi). Jakarta: AP21 Nasional. 
Jan H. 2008. Corporate Social Responsibilty \& Sustainability Reporting. Bandung (ID): IAI.

Milen, Anni, 2006. What Do We Know About Capacity Building? An Overview of Existing Knowledge and Good Practice, World Health Organization. Departement of Health Service Provision, Geneva.

Rahmana, Arief. 2009. Usaha Kecil dan Menengah (UKM), informasi terdepan tentang usaha kecil menengah. Online http://infoukm.wordpress.com

Ratnasasi, J.R, Makmur, M, Ribawanto, H. 2014. Pengembangan Kapasitas (Capacity Building)

Kelembagaan Pada Badan Kepegawaian Daerah Kabupaten Jombang. Jurnal Administrasi Publik (JAP), Vol. 1, No.3

Ruhana I. 2012. Pengembangan kualitas sumber daya manusia vs Daya Saing Global. J Profit.
6(1):50-56.

Soeprapto, Riyadi. 2006.

Pengembangan Kapasitas

Pemerintah Daerah Menuju

Good Governance. Jurnal

Ilmiah Administrasi Publik,

Volume IV (1), FIA

UNIBRAW, Malang.

Sugiyono. 2015. Metode Penelitian

Kualitatif dan Kuantitatif.

Bandung: PT. Alfabeta.

Tarance Morrison. 2001. Actionable Learning - A Handbook for Capacity Building through Case Based Learning. $A D B$ Institute.

UURI, Kepala Biro Peraturan Perundang-undangan Bidang Perekonomian dan Perindustrian. 2008. Undangundang Republik Indonesia Nomor 20 Tahun 2008 tentang Usaha Mikro, Kecil dan Menengah. Jakarta (ID): Kepala Biro Peraturan Perundang-undangan Bidang Perekonomian dan Perindustrian. 